\title{
Extension of the Postharvest Life of Nectarine Using Modified Atmosphere Packaging and Potassium Permanganate Treatment
}

\author{
Erdinç Bal*
}

Horticulture Department, Faculty Agriculture, Tekirdă̆ Namık Kemal University, 59000 Tekirdă̆, Turkey

\begin{tabular}{l}
\hline A R T I C L E I N F O \\
Research Article \\
Received 12 April 2018 \\
Accepted 03 September 2018 \\
\hline
\end{tabular}

Keywords:

Nectarine

Postharvest

MAP

Biochemical compounds

Ethylene scrubbers

*Corresponding Author:

E-mail: ebal@nku.edu.tr \begin{abstract}
A B S T R A C T
The effects of combinations of modified atmosphere packaging (MAP) with potassium permanganate $\left(\mathrm{KMnO}_{4}\right)$ based ethylene scrubbers on the storage life and fruit quality of nectarine (Prunus persica cv. Bayramiç Beyazı) were investigated. Three different types of ethylene sachets (contained 3, 7 and $10 \mathrm{~g} \mathrm{KMnO}_{4}$ ) were used and placed beside fruits in polypropylene baskets then lined with MAP. Fruits were stored at $0-1{ }^{\circ} \mathrm{C}$ and $90 \%$ relative humidity throughout 40 day. During the cooling storage period, $\mathrm{O}_{2}$ and $\mathrm{CO}_{2}$ percentage in MAP, fruit firmness, total soluble solids, titratable acidity, ascorbic acid, total flavonoid content, total phenolic content, total antioxidant content and chilling injury (CI) were determined at 10 day interval. $\mathrm{KMnO}_{4}$ treated fruits had shown delayed ripening, reduced respiration and retained of higher firmness. As the dose of $\mathrm{KMnO}_{4}$ treatment increased, it was determined more positive effect on fruit quality. $10 \mathrm{~g} \mathrm{KMnO}_{4}$ treatment was most effective in the retention of higher biochemical compounds and inhibition of CI symptoms. The results indicate that $\mathrm{KMnO}_{4}$ treatment, as well as MAP application, should be highly recommended for retaining the fruit quality of cold-stored 'Bayramiç Beyazı' nectarines and fruits treated with $10 \mathrm{~g}$ doses of $\mathrm{KMnO}_{4}$ could be stored for 40 days with good quality.
\end{abstract}

DOI: https://doi.org/10.24925/turjaf.v6i10.1362-1369.1972

\section{Introduction}

Nectarine is one of the most important and popular fruit consumed worldwide due to its delicious flavour and attractive appearance. Nectarine fruits are usually rich in vitamins and the other antioxidant compounds, including various phenolics (Garcia-Parra et al., 2011). However, they deteriorate rapidly after harvest and usually results in a short limited postharvest life (Özkaya et al., 2016). Cold storage is the most commercially adopted technique, and a cold chain has been integrated into the post-harvest management systems (Lurie and Crisosto, 2005). The storage life of nectarines under ideal conditions of $0^{\circ} \mathrm{C}$ and high relative humidity $(90-95 \%)$ is limited to $2-4$ weeks (Karen, 1991). When cold temperature combined with modified atmosphere, it causes reducing the produce respiration rate, ripening delay, inhibiting the growth of many spoilage organisms and keeps fruit according to market needs (Kader and Saltveit, 2003). Modified atmosphere is a quite versatile, relatively simple, and low cost technology that can be applied to various types of fruit and vegetables (Silva et al., 2009). Its efficacy can be increased by combining it with ethylene absorbers.
The presence of ethylene in the storage and packing atmosphere has been a major concern for unripe climacteric fruits during postharvest handling, because it accelerates ripening, senescence, abscission and physiological disorders and subsequent postharvest pathogenic infection (Sujayasree and Fasludeen, 2017). The action of ethylene must be avoided during storage and transportation. In peaches and nectarines the greatest increase in ethylene is often after the ripening related changes have already occurred (Lill et al., 1989). The removal of ethylene and/or inhibition of the effect of ethylene in stored environments are fundamental to maintaining postharvest quality of climacteric produce (Saltveit, 1999). There are several compounds that can be used as inhibitors of ethylene, for example aminoethoxyvinylglycine (AVG), an inhibitor of ethylene synthesis; 1-Methylcyclopropene (1-MCP), an inhibitor of ethylene action and potassium permanganate $\left(\mathrm{KMnO}_{4}\right)$, an oxidizing agent (Sen et al., 2012).

One of the main mechanisms of action of ethylene scavengers is based on the use of $\mathrm{KMnO}_{4}$, which oxidizes ethylene to carbon dioxide and water (Abe and Watada, 
1991; Wills and Warton, 2004). Due to the presence of double bond, ethylene $\left(\mathrm{H}_{2} \mathrm{C}=\mathrm{CH}_{2}\right)$ is very reactive and is rapidly oxidized to acetate and ethanol by $\mathrm{KMnO}_{4}$ (Lopez-Rubio et al. 2004). $\mathrm{KMnO}_{4}$ is usually imbedded in different inert substrates such as silica gel incorporated inside high permeable sachets, films or filters (Mehyar and Han, 2011). These products remove unwanted ethylene gas through the oxidation process, thereby ensuring the quality of freshness of the product in a packaged or bulk environment while in transportation or storage. $\mathrm{KMnO}_{4}$ oxidizes ethylene and changes colour from purple to brown, and thus, a colour change indicates its residual ethylene absorbing capacity (Smith et al. 2009). Dual application of $\mathrm{KMnO}_{4}$ and film liner would be highly desirable for maintaining fruit quality during cold storage. The use of $\mathrm{KMnO}_{4}$ in conjunction with modified atmosphere in polyethylene films delayed fruit ripening, maintained quality and extended shelf life in many climacteric fruits such as avocado (Illeperuma and Nikapitiya, 2002), apple (Chaves et al., 2007; Sardabi et al., 2014), mango (Azad et al., 2008; Elzubeir et al., 2017), papaya (Silva et al., 2009; Reboucas et al., 2013), kiwifruit (Bal and Celik, 2010), apricot (Ishaq et al., 2009; Ali et al., 2015), peach (Bal, 2016), tomato (Kostekli et al., 2016) and sapodilla (Freitas et al., 2017). However, there is no information available regarding the effects of $\mathrm{KMnO}_{4}$ treatment and MAP on physiological and biochemical changes in nectarine fruits.

The objective of this work was to evaluate the effect of different doses of $\mathrm{KMnO}_{4}$ on the extension of postharvest life of 'Bayramiç Beyazı' nectarine, stored under modified atmosphere.

\section{Materials and Methods}

\section{Plant Materials}

Nectarines (Prunus persica cv. Bayramiç Beyazı) used in this study were hand-harvested from a local orchard (Çanakkale, Turkey) at firm-ripe stage and immediately transported via ventilated truck to cold storage facilities of Department of Horticulture, Faculty of Agriculture, Namik Kemal University where they were sorted and selected for similar size, uniform maturity and appearance and freedom from defects.

\section{$\mathrm{KMnO}_{4}$ and MAP Treatments}

The fruits were distributed among the four treatments in a completely randomized design with three replicates. Three different types of ethylene sachets (Dongguan Dingxing Industry Co., Ltd), contained $3 \mathrm{~g}$ ethylene absorber $(45 \times 50 \mathrm{~mm}), 7 \mathrm{~g}$ ethylene absorber $(45 \times 60 \mathrm{~mm})$ and $10 \mathrm{~g}$ ethylene absorber $(65 \times 70 \mathrm{~mm})$ were used in the study. The ethylene absorbent was ethylene sachets contained a mixture of natural clays and $\mathrm{KMnO}_{4}$. Sachets were made from Tyvek, a high quality material suitable for contact with food products, which allows gaseous interchanges. $\mathrm{KMnO}_{4}$ sachets were placed beside fruits in polypropylene baskets $(1 \mathrm{~kg})$ then lined with MAP. Control fruits packed only with MAP. After all treatments, packages were transferred to a storage room at $0-1{ }^{\circ} \mathrm{C}$ and $90 \%$ relative humidity for 40 days. Nectarine fruits were evaluated by analysing the physicochemical and biochemical attributes using the following parameters at 0 days and at a regular interval of 10 days until the end of storage period.

\section{Assessment of Fruit Quality Attributes}

In MAP packages, $\mathrm{O}_{2}$ and $\mathrm{CO}_{2}$ gas composition percentages were measured with a checkpoint $\mathrm{O}_{2} / \mathrm{CO}_{2}$ gas analyzer (Systech Gaspace advance GS3L, England) during storage.

Fruit firmness was determined using a hand-held penetrometer with an $8 \mathrm{~mm}$ long measuring plunger on the pared equatorial surface on 2 sides of the fruit and was expressed as Newton (N).

For the analysis of soluble solids content (SSC) and titratable acidity (TA) of each sample, tissue sap was squeezed out from fresh fruit materials with a press. In this juice, SSC were determined with a hand refractometer $(\%)$. TA content was determined by titrating method and calculating the result as grams of malic acid per $100 \mathrm{~g}$ fresh weight $(\%)$.

Ascorbic acid content of the samples was determined according to the recommended method of AOAC (2000) using 2, 6-dichlorophenol indophenol and expressed as $\mathrm{mg} \mathrm{kg}^{-1}$.

Total phenolics of the nectarine extract were quantified spectrophotometrically using Folin-Ciocalteu reagent based on the method (Slinkard and Singleton, 1977). Results were expressed as mg (gallic acid equivalent) $100 \mathrm{~g}^{-1}$.

The total flavonoid contents were measured by a colorimetric assay (Zhishen et al., 1999) and the results were expressed as $\mathrm{mg}$ (routine equivalent) $100 \mathrm{~g}^{-1}$.

Total antioxidants was determined by 2, 2-diphenyl-1picrylhydrazyl (DPPH) free radical-scavenging method as described by Brand-Williams et al. (1995) and was expressed as $\mu \mathrm{mol}$ (Trolox equivalent) $\mathrm{g}^{-1}$.

For evaluation of chilling injury, nectarine fruits were longitudinally cut into halves for the evaluation of the occurrence of chilling injury (CI) according to the severity of exocarp browning and flesh translucency (Khan et al., 2011). CI was estimated visually as the percentage of the affected area compared with the total surface area of each section on a scale where: $0=$ no change; $1=$ less than $10 \% ; 2=10-25 \% ; 3=25-50 \% ; 4=$ $50-75 \%$; and $5=$ more than $75 \%$.

\section{Statistical Analyses}

The experiment was of a completely randomized factorial design of three replications with two kilogram of fruit per plot. Analysis of Variance (ANOVA) was the means for analysing the difference between means and while LSD test being applied for mean separation at $\mathrm{P}<0.05$. All the analyses were carried out through SPSS as statistical software. Results are reflected as the mean \pm SE.

\section{Result and Discussion}

\section{$\mathrm{O}_{2}$ and $\mathrm{CO}_{2}$ Levels in MAP}

MAP technology has been successfully used to maintain the postharvest quality and to prolong the storage period of many fruit and vegetables by creating higher $\mathrm{CO}_{2}$ and lower $\mathrm{O}_{2}$ concentrations in the surrounding atmosphere of the commodities (Kader and Watkins, 2000). In the study, $\mathrm{O}_{2}$ and $\mathrm{CO}_{2}$ levels detected in the sample packages during storage are reported in Figure 1. As expected, a decrease in the headspace $\mathrm{O}_{2}$ 
concentration, as well as an increase in the headspace $\mathrm{CO}_{2}$ concentration, was observed during storage for all of the treatments. Up to $30^{\text {th }}$ day of storage, there was no significant difference in respiration rate in the fruits treated with $\mathrm{KMnO}_{4}$. However, marked difference was recorded in $\mathrm{O}_{2}$ and $\mathrm{CO}_{2}$ level at $40^{\text {th }}$ days of storage under all the treatments. At $40 \mathrm{t}^{\mathrm{h}}$ day of storage, in control and 3 g $\mathrm{KMnO}_{4}$ treated fruits, $\mathrm{CO}_{2}$ level increased more and $\mathrm{O}_{2}$ level decreased more than other applications. These results indicate that 7 and $10 \mathrm{~g} \mathrm{KMnO}_{4}$ doses are more effective than the other two treatments in inhibition of respiration rates during 40 days of storage at $0^{\circ} \mathrm{C}$ which are in agreement with the previous reports suggesting the beneficial effects of $\mathrm{KMnO}_{4}$ in reducing respiration rates by oxidizing ethylene in avocado (Illeperuma and Nikapitiya, 2002), papaya (Silva et al., 2009) and peach (Bal, 2016). Comparatively higher respiration levels under control and $3 \mathrm{~g} \mathrm{KMnO}_{4}$ treated fruits were mainly contributed by two factors namely, acceleration of ripening and occurrence of chilling injury. Chilling injury is known for abrasion of cell membrane and other cell organelles which leads higher cell respiration rate (Valenzuela et al., 2017).

\section{Firmness}

Firmness is an important quality attribute in nectarine, and excessive softening is one of the main factors reducing quality and limiting commercialization for fresh consumption (Kader and Mitchell, 1989). In the present study, fruit firmness at harvest was $66.6 \mathrm{~N}$ and progressively decreased during storage (Figure 2). Softening of nectarine fruits was remarkably delayed with $\mathrm{KMnO}_{4}$ treatments compared to control. At the end of the storage, the highest firmness was recorded in $10 \mathrm{~g}$ $\mathrm{KMnO}_{4}$ treated fruits $(55.8 \mathrm{~N})$ followed by $7 \mathrm{~g} \mathrm{KMnO}_{4}$ treated fruits $(52.9 \mathrm{~N})$ while lowest firmness was recorded in control fruits $(39.2 \mathrm{~N})$. According to the results, within doses of $\mathrm{KMnO}_{4}$, lower firmness loss was seen in fruits treated with $3 \mathrm{~g} \mathrm{KMnO}_{4}$. It may be due to the increasing in concentration of $\mathrm{KMnO}_{4}$ absorber and decrease in the ripening rate, hence, softening of fruit were minimum. Similar results were obtained by Bal and Celik (2010), Sharma et al. (2012) and Kostekli et al. (2016) who reported that $\mathrm{KMnO}_{4}$ induced ethylene retardation and caused a delay in fruit softening in kiwifruit, plum and tomato respectively.

\section{SSC}

Soluble solids content is one of the main internal qualities of nectarine fruits. In the present study, there was significantly an increase in SSC as the fruit ripens in all treatments. Similarly, this increase was reported in nectarine fruits by Akbudak and Eris (2004), Kaynas et al. (2005) and Özdemir et al. (2006). The increase in SSC was mainly due to conversion of starch to soluble forms of sugars. Figure 3 shows the increasing pattern of SSC in nectarine fruit during storage. Higher rises in SSC were observed in control where initial contents $(11.7 \%)$ increased to $14.4 \%$ followed by $3 \mathrm{~g} \mathrm{KMnO}_{4}(14 \%)$, while $7 \mathrm{~g} \mathrm{KMnO}_{4}$ and $10 \mathrm{~g} \mathrm{KMnO}_{4}$ maintained a minimum SSC $(12.6 \%$ and $12.4 \%)$ at the $40^{\text {th }}$ day respectively. The reason for delaying the metabolic activity of fruits treated with $\mathrm{KMnO}_{4}$ (especially 7 and $10 \mathrm{~g}$ ) during storage due to delay in increasing SSC. Maintaining $\mathrm{SSC}$ by $\mathrm{KMnO}_{4}$ treatments has been observed in apple (Chaves et al., 2007), papaya (Silva et al., 2009) and mango (Elzubeir et al., 2017).

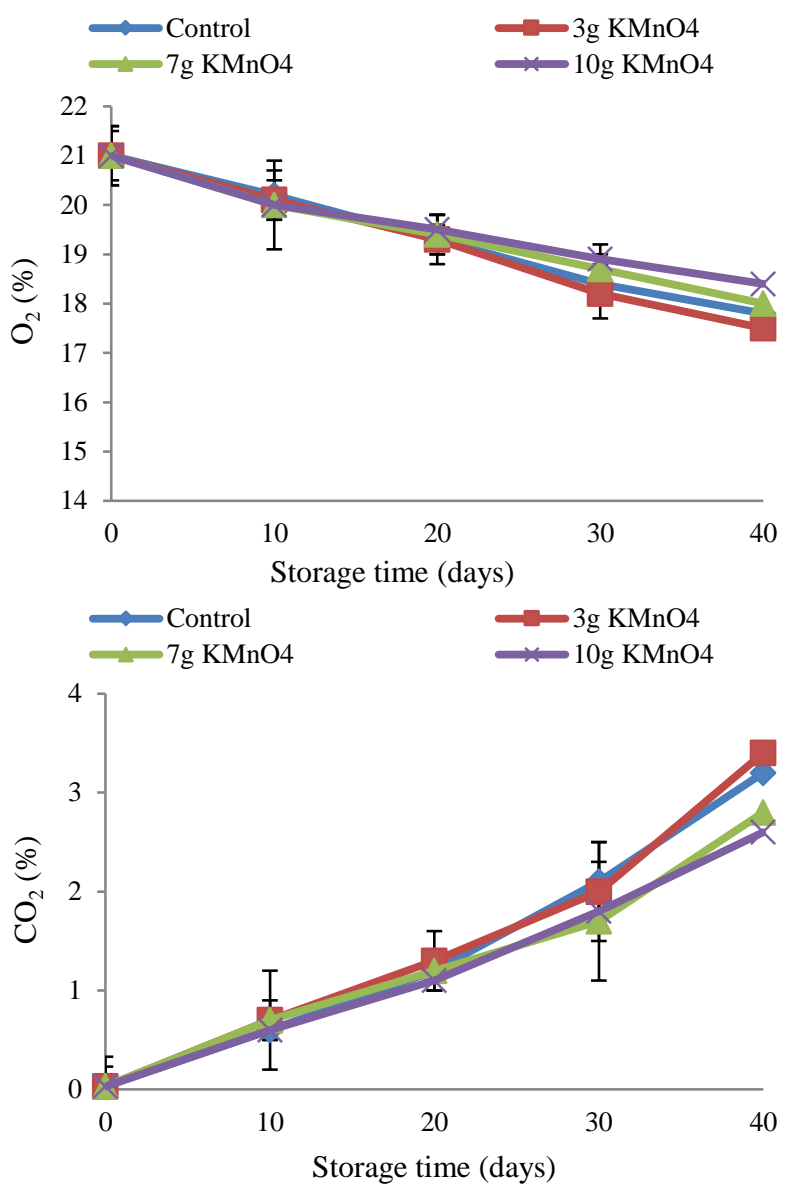

Figure 1 Effects of ethylene absorbent treatments on $\mathrm{O}_{2}$ and $\mathrm{CO}_{2}$ concentrations in MAP

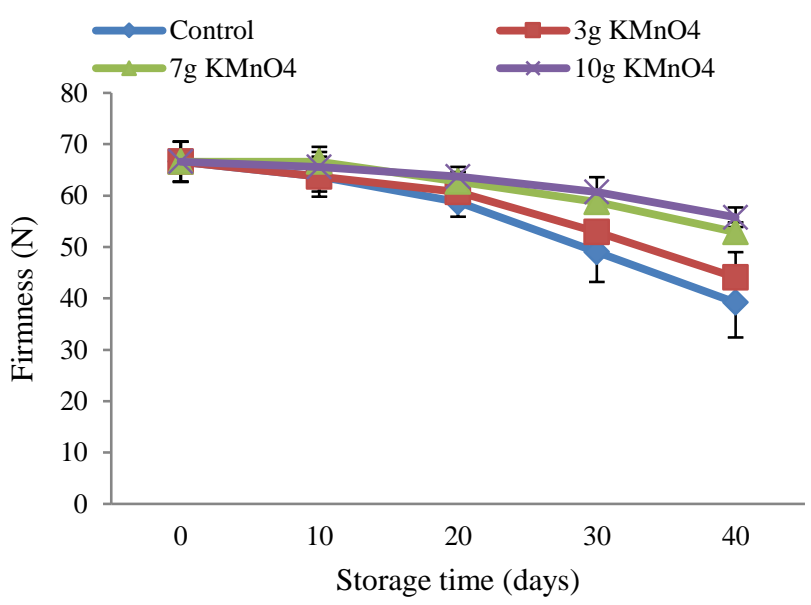

Figure 2 Effects of ethylene absorbent treatments on firmness of nectarine fruits

$T A$

TA is directly associated with organic acids in fruits, and a reduction in acidity may be expected as a result of metabolic changes in fruit due to the use of organic acids in the respiratory process (Maftoonazad et al., 2008). The content of TA in the nectarine fruit decreased gradually during the storage and this decline was retarded by especially 7 and $10 \mathrm{~g} \mathrm{KMnO}_{4}$ treatments (Figure 4). 


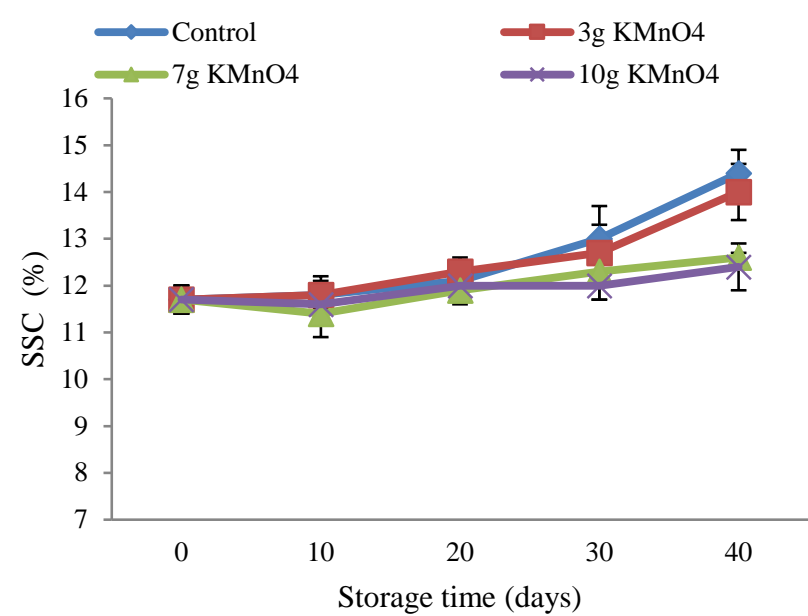

Figure 3 Effects of ethylene absorbent treatments on SSC

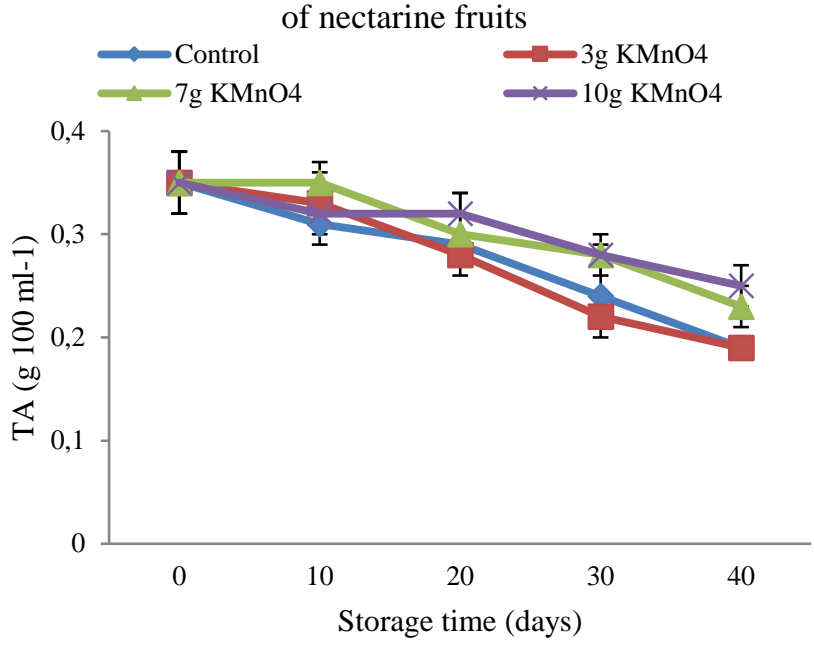

Figure 4 Effects of ethylene absorbent treatments on TA of nectarine fruits

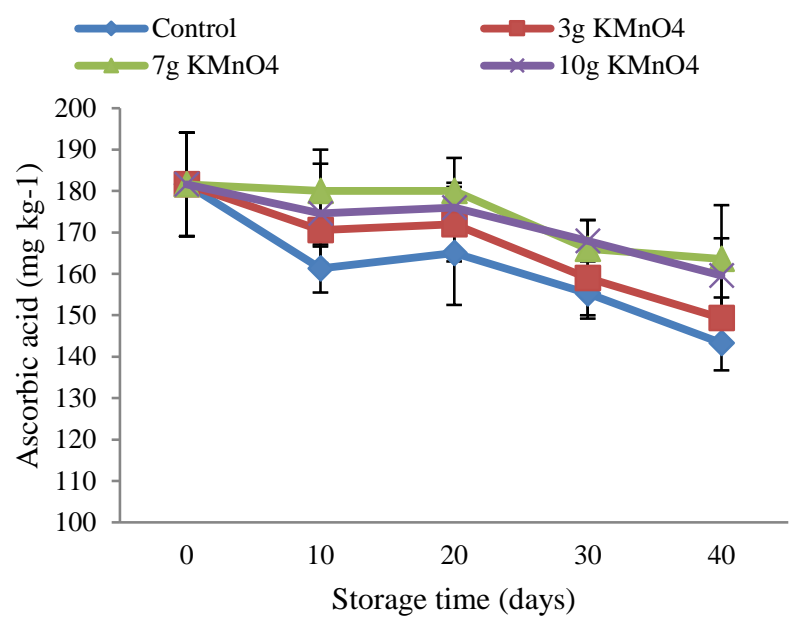

Figure 5. Effects of ethylene absorbent treatments on ascorbic acid of nectarine fruits

The treatment with low levels $(3 \mathrm{~g})$ of $\mathrm{KMnO}_{4}$ was no effective in delaying the loss of TA. At the beginning of storage, TA of nectarines was $0.35 \%$. At $40^{\text {th }}$ day of storage, while the lowest TA content of nectarines was detected in control (0.19\%) and $3 \mathrm{~g} \mathrm{KMnO}_{4}(0.19 \%)$ treatments, the highest TSS content was determined in 7 $(0.23 \%)$ and $10 \mathrm{~g} \mathrm{KMnO}_{4}(0.25 \%)$ treatments. It was observed that an increase in the permanganate level inside the packing significantly reduced the titratable acidity.
The retention of acidity in higher concentrations of $\mathrm{KMnO}_{4}$ might be due to reduction in metabolic changes of organic acid into carbon dioxide and water. Similarly, fruits, such as banana, kiwifruit, tomato and mango, have also been reported to be more acidity when treated with $\mathrm{KMnO}_{4}$ (Elamin and Abu-Goukh, 2009; Bal and Celik, 2010; Kostekli et al. 2016; Elzubeir et al., 2017).

\section{Ascorbic Acid Content}

Ascorbic acid is an important nutrient and is highly sensitive to degradation due to its oxidation compared to other nutrients during processing and storage in fruits and vegetables (Rickman et al., 2007). Lee and Kader (2000) reported that the ascorbic acid levels generally tend to decrease during the storage of the most fruits. The data belonging to ascorbic acid content is shown in Figure 5. The ascorbic acid content of the fruit was the highest (181.6 mg kg-1) at the beginning of storage and it decreased with the advancement of storage period. However, this trend was slower in 7 and $10 \mathrm{~g} \mathrm{KMnO}_{4}$ treated fruits. At the end of the storage, the highest ascorbic acid content was determined in 7 and $10 \mathrm{~g}$ $\mathrm{KMnO}_{4}$ treated fruits $\left(163.6 \mathrm{mg} \mathrm{kg}^{-1}\right.$ and $\left.159.6 \mathrm{mg} \mathrm{kg}^{-1}\right)$, while the lowest ascorbic acid content was determined in control fruits $\left(143.3 \mathrm{mg} \mathrm{kg}^{-1}\right)$. Vitamin C is one of the respiratory metabolites, which means it is possible that the faster diminution could cause by the higher respiration rate observed in these treatments. This effect can be associated with the property of $\mathrm{KMnO}_{4}$ on reducing or delaying the activity of ascorbate oxidase and consequently maintaining ascorbic acid content. These results are in line with Reboucas et al. (2013) and Freitas et al. (2017) who had used the ethylene absorbers. Ishaq et al. (2009) also reported that $\mathrm{KMnO}_{4}$ treatment maintained higher ascorbic acid concentrations compared to non-treated apricot fruits due to slower respiration or less oxidation of ascorbic acid in fruit treated with $\mathrm{KMnO}_{4}$.

\section{Total Flavonoid Content}

Flavonoids, a special group of polyphenols, are pigments responsible for the color and flavor of many fruits, vegetables, flowers, nuts, and seeds (Harborne and Williams, 2000). In the study, total flavonoid contents of nectarines generally tended to increase during storage even though there were fluctuations in flavonoid content (Figure 6). However, this rise was more pronounced in control fruits depending on maturation. The total flavonoid contents of samples at the beginning of storage were about $83.2 \mathrm{mg} 100 \mathrm{~g}^{-1}$. The highest total flavonoid content was obtained from control treatment $(102.3 \mathrm{mg}$ $100 \mathrm{~g}^{-1}$ ) on $30^{\text {th }}$ day, and then sharply decreased to 85.3 $\mathrm{mg} 100 \mathrm{~g}^{-1}$ on $40^{\text {th }}$ day. The results indicated that the total flavonoids of control fruits gradually decreased as maturity proceeded. Whereas, in fruit treated with $\mathrm{KMnO}_{4}$, total flavonoid retained better. 7 and $10 \mathrm{~g}$ $\mathrm{KMnO}_{4}$ treated fruits showed to be the most effective treatment for maintaining flavonoid content in fruits. Similarly, Bal (2016) also reported that variations in phenolic compound content and flavonoid content were slower in $\mathrm{KMnO}_{4}$ treated fruits than control group throughout storage period. Slower reduction of biochemical compound in $\mathrm{KMnO}_{4}$ treated fruits than 
control might be attributed to antisenescence properties of $\mathrm{KMnO}_{4}$ (Abe and Watada, 1991; Kadu and Gajipara, 2009).

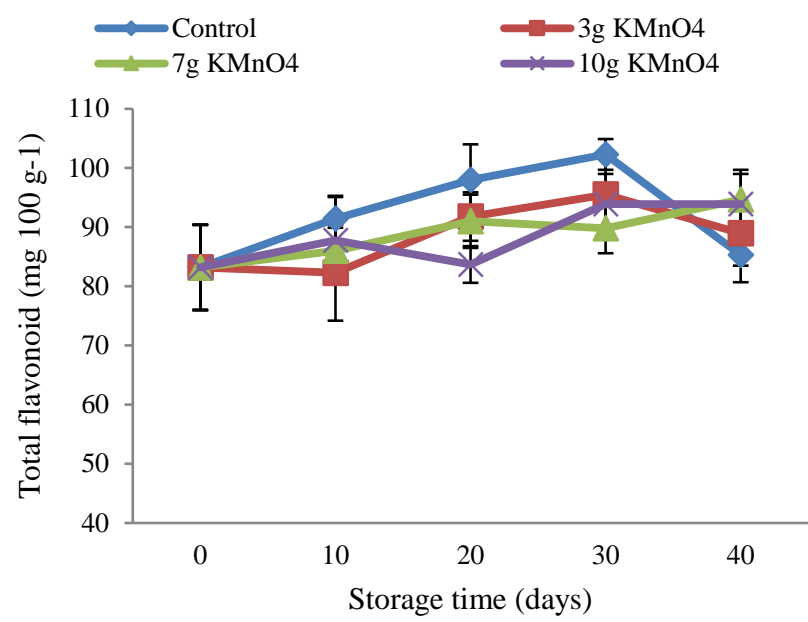

Figure 6 Effects of ethylene absorbent treatments on total flavonoid of nectarine fruits

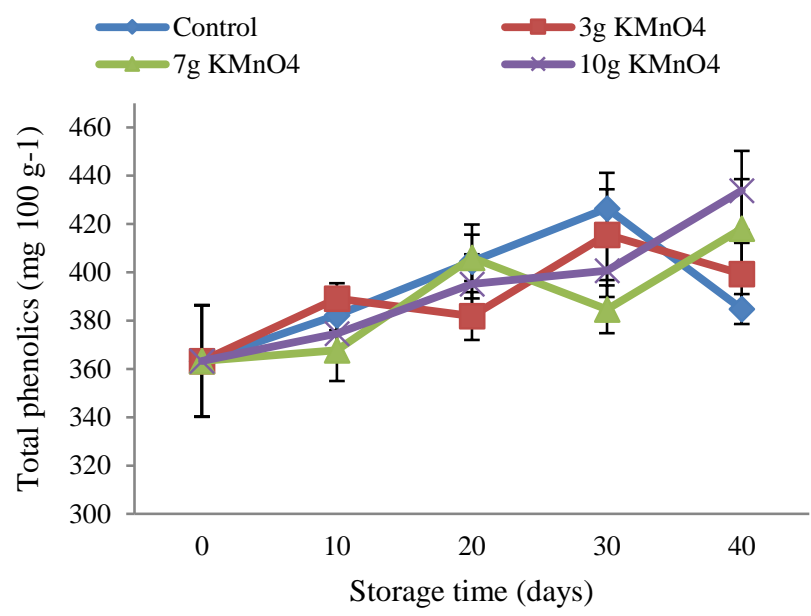

Figure 7 Effects of ethylene absorbent treatments on total phenolic content of nectarine fruits

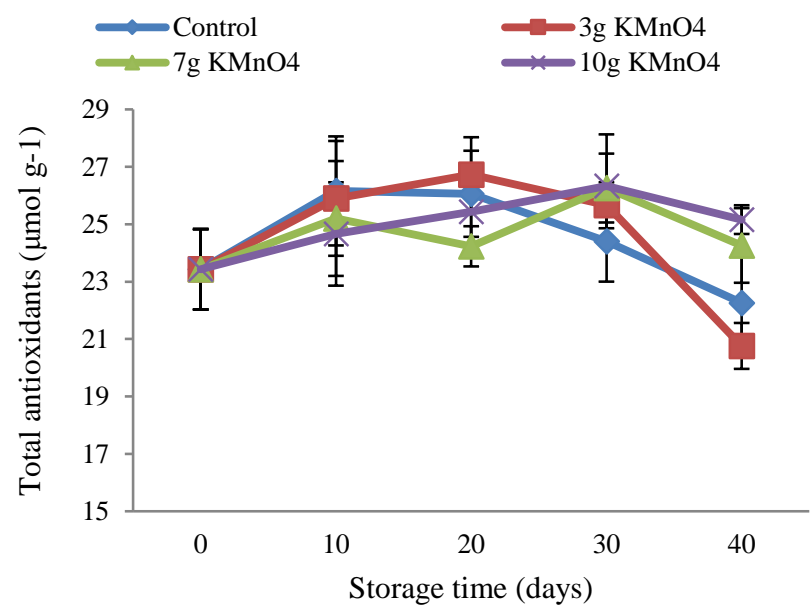

Figure 8 Effects of ethylene absorbent treatments on total antioxidant content of nectarine fruits

\section{Total Phenolic Content}

Phenolic compounds are widely distributed in fruit and vegetables and represent, together with ascorbic acid, one of the major contributors to antioxidant capacity
(Cefola et al., 2014). Nectarine fruit is also usually rich in vitamins and the other antioxidant compounds, including various phenolics (Garcia-Parra et al., 2011). The initial total phenolic content in the nectarines was $363.3 \mathrm{mg} 100$ $\mathrm{g}^{-1}$ (Figure 7). Changes in total phenolic content over the postharvest period were also similar in trend to those for flavonoid content. Generally, the content of the detected phenols showed an increase in the first 10 days of storage, followed by fluctuations in the next days. However, $\mathrm{KMnO}_{4}$ treatments maintained total phenolic content compared to control at the end of the storage. At $40^{\text {th }}$ day of storage, the highest total phenolic content was recorded in $10 \mathrm{~g} \mathrm{KMnO}_{4}$ treated fruits (433.9 mg $100 \mathrm{~g}^{-1}$ ) followed by $7 \mathrm{~g} \mathrm{KMnO}_{4}$ treated fruits $\left(418.1 \mathrm{mg} 100 \mathrm{~g}^{-1}\right)$, while lowest total phenolic content was recorded in control fruits $\left(384.8 \mathrm{mg} 100 \mathrm{~g}^{-1}\right) . \mathrm{KMnO}_{4}$ treatments delayed the onset of the maximum value of total phenol content, and maintained a higher level of total phenol in the fruit at the end of storage. This phenomenon of total phenolics accumulation can be attributed to the role of ethylene in phenolic metabolism (Blankenship and Unrath, 1988). The results were in agreement with previous studies (Ali et al., 2015; Bal, 2016), which found that when ethylene production of fruit was suppressed by ethylene absorbers, the accumulation of total phenolics could be delayed or reduced. Moreover, it is thought that from the thirtieth day, increased progressively chilling injury in control and $3 \mathrm{~g} \mathrm{KMnO}_{4}$ treated fruits leaded to a fast decrease in phenolic compounds. Tomas-Barberan et al. (2001) also reported that the chilling injury and browning promoted polyphenol oxidase activities and caused a decreasing of total phenols of fruits.

\section{Total Antioxidants}

Antioxidant activity of fruit is contributed by several bioactive compounds like phenolics, flavonoids, ascorbic acid (Wang et al., 1996). The increase in antioxidant content during storage is an indicator of ripening process where phytochemicals attained maximum accumulation. Similarly, a decrease in antioxidant content during subsequent storage is attributed to the oxidation of phenolic contents and ascorbic acid (Ali et al., 2015). In the present study, antioxidant activity was $16.9 \mu \mathrm{mol} \mathrm{g} \mathrm{g}^{-1}$ at the beginning of the experiment (Figure 8). The results indicated that antioxidant content exhibited an initially increasing trend until to maximum and then began to decrease during subsequent storage. The increase in the antioxidant content could be attributed to the synthesis of some compounds, such as phenols, flavonoids depending on maturation (Zhao et al., 2015). At $40^{\text {th }}$ day, the highest antioxidant content was recorded in $10 \mathrm{~g} \mathrm{KMnO}_{4}$ treatment $\left(25.16 \mu \mathrm{mol} \mathrm{g} \mathrm{g}^{-1}\right)$ followed by $7 \mathrm{~g} \mathrm{KMnO}_{4}$ treatment $\left(24.26 \mu \mathrm{mol} \mathrm{g} \mathrm{g}^{-1}\right)$, while lowest antioxidant content was recorded respectively in $3 \mathrm{~g} \mathrm{KMnO}_{4}(20.76$ $\left.\mu \mathrm{mol} \mathrm{g}{ }^{-1}\right)$ and control $\left(22.26 \mu \mathrm{mol} \mathrm{g}^{-1}\right)$ treatments. $7 \mathrm{~g}$ $\mathrm{KMnO}_{4}$ or $10 \mathrm{~g} \mathrm{KMnO}_{4}$ treatments effectively postponed the onset of the maximum of antioxidant activity due to retaining maturation period. This indicated that ethylene absorbers were able to maintain higher antioxidant activity in nectarines by delaying the senescence and decay in fruits, as also reported by Ali et al. (2015) and Mir et al. (2018). In addition, the results of this study confirmed that the highest accumulation of antioxidant 
activities in chilling-tolerant nectarine fruits $(7 \mathrm{~g}$ and $10 \mathrm{~g}$ $\mathrm{KMnO}_{4}$ ) was associated with resistance to CI. Kostekli et al. (2016) also reported that the percent loss of ascorbic acid and antioxidant capacity was significantly lower in tomatoes stored with ethylene absorber sachets as compared to tomatoes.

\section{Evaluation of $C I$}

CI reduces postharvest quality of fruits and is genetically influenced by a combination of storage temperature and storage period (Crisosto et al., 1999). In this study, compared with the control nectarines, ethylene absorber treatment delayed and reduced the CI in nectarine fruit during the cold storage (Figure 9). All of treated nectarines did not show any CI symptoms till 20 days of storage. However, chilling injury index of the control fruits progressed rapidly after 30 days and got the highest score during other analysis periods. CI symptoms were first visible as exocarp browning and flesh translucency on the $30^{\text {th }}$ day in control and $3 \mathrm{~g} \mathrm{KMnO}_{4}$ treatments. At the end of storage, the highest $\mathrm{CI}$ value was determined in control fruits (2 point), while no CI symptom was recorded in $10 \mathrm{~g} \mathrm{KMnO}_{4}$ treated fruits followed by $7 \mathrm{~g}$ ( 0.3 point) and $3 \mathrm{~g} \mathrm{KMnO}_{4}$ (1.6 point) treatments. The lower CI symptoms in nectarines treated with $\mathrm{KMnO}_{4}$ may be due to slower metabolic rates and retention of various bioactive compounds in fruits. This result is in agreement with previous reports showing that use of absorbent sachets can be used to reduce internal breakdown development during storage (Pesis et al., 2002; Bal, 2016). Moreover, CI may be related to tissue deterioration or senescence, which leads to changes in membrane permeability and in biochemical compounds (Lurie and Crisosto, 2005). Therefore, it was seen that 10 g $\mathrm{KMnO}_{4}$ treated fruits which had no $\mathrm{CI}$ symptom maintained better firmness and biochemical compounds of fruits.

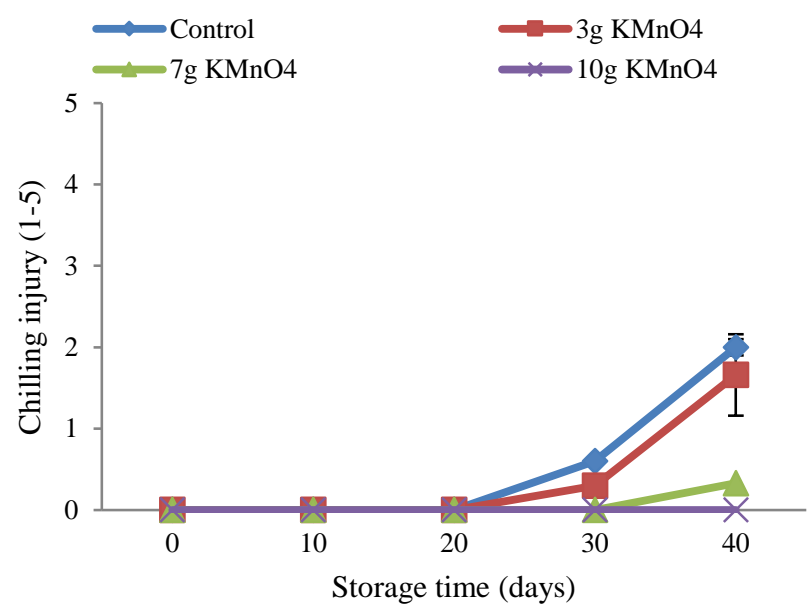

Figure 9 Effects of ethylene absorbent treatments on chilling injury of nectarine fruits

\section{Conclusion}

The results of this study indicated that $\mathrm{KMnO}_{4}$ treatment ethylene absorbent along with MAP appeared to maintain fruit quality of nectarine during cold storage. $\mathrm{KMnO}_{4}$ dose influenced the fruit quality, where in the concentration of $10 \mathrm{~g}$ of $\mathrm{KMnO}_{4}$ per $\mathrm{kg}$ of fruit was the most efficient in inhibition of respiration rates and CI symptoms, retarding the loss of firmness and maintaining biochemical compounds of nectarine fruits. Results showed that $10 \mathrm{~g} \mathrm{KMnO}_{4}$ treatment combined with MAP showed promising results for maintaining nectarine quality and extending storage life at $0-1^{\circ} \mathrm{C}$ for 40 days.

\section{References}

Abe K, Watada A. 1991. Ethylene absorbent to maintain quality of lightly processed fruits and vegetables. J. Food Sci., 56: 1589-1592.

Akbudak B, Eris A. 2004. Physical and chemical changes in peaches and nectarines during the modifed atmosphere storage. Food Control, 15: 307-313. DOI: 10.1016/S09567135(03)00082-3.

Ali S, Masud T, Ali A, Abbasi KS, Hussain S. 2015. Influence of packaging material and ethylene scavenger on biochemical composition and enzyme activity of apricot cv. Habi at ambient storage. Food Sci. Qual. Manag., 35: 73-82.

A.O.A.C. 2000. Association of official and analytical chemists. $15^{\text {th }}$ Ed (Helrich K.). Arlington, Virgina, USA.

Azad MI, Mortuza MG, Nahar NA, Huq S, Alam MA. 2008. Effect of potassium permanganate on physico-chemical changes and shelf life of mango (Mangifera indica L.). The Agriculturists, 6(1): 54-59. DOI: 10.3329/agric.v6i1.5214.

Bal E, Celik S. 2010. The Effects of postharvest treatments of salicylic acid and potassium permanganate on the storage of kiwifruit. Bulg. J. Agric. Sci., 16(2): 576-584.

Bal E. 2016. Effect of modified atmosphere packing and potassium permanganate treatments on storage of J.H.Hale peach cultivars. Iğdır University Journal of the Institute of Science and Technology, 6(1): 9-15.

Blankenship SM, Unrath CR. 1988. PAL and ethylene content during maturation of red and golden delicious apples. Phytochemistry, 27(4): 1001-1002. DOI: 10.1016/00319422(88)80260-7.

Brand-William W, Cuvelier ME, Berset C. 1995. Use of a free radical method to evaluate antioxidant activity. Lebenson Wiss Technol., 28: 25-30.

Cefola M, Pace B, Sergio L, Baruzzi F, Gatto MA, Carito A, Linsalata V, Cascarano NA, Venere D. 2014. Postharvest performance of fresh-cut 'Big Top' nectarine as affected by dipping in chemical preservatives and packaging in modified atmosphere. Int. J. Food Sci. Technol., 49: 118495. DOI: $10.1111 /$ ijfs. 12415 .

Chaves MA, Bonomo RCF, Silva AAL, Santos LS, Carvalho BMA, Souza TS, Gomes G, Soares RD. 2007. Use of potassium permanganate in the sugar apple post-harvest preservation. Cienc. Tecnol. Aliment., 5(5): 346-351. DOI: 10.1080/11358120709487711.

Crisosto CH, Mitchell FG, Ju Z. 1999. Susceptibility to chilling injury of peach, nectarine, and plum cultivars grown in California. HortScience, 34: 1116-1118.

Elamin MA, Abu-Goukh AA. 2009. Effect of polyethylene film lining and potassium permanganate on quality and shelf-life of banana fruits. Gezira J. Agric. Sci., 7: 217-230.

Elzubeir MM, Abu-Goukh ABA, Osman A. 2017. Effect of polyethylene film lining and potassium permanganate on quality and shelf-life of mango fruits. J. Environ. Soc. Sci., 4(1): 130.

Freitas S, Edelky W, Almeida B, Lucilania M, Morais D, Lígia P, Moura C, Kaynne A, Rui S. 2017. Potassium permanganate effects on the quality and post-harvest conservation of sapodilla (Manilkara zapota (L.) P.Royen) fruits under modified atmosphere. Acta Agronómica, 66(3): 331-337. DOI: 10.15446/acag.v66n3.54579. 
Garcia-Parra J, Gonzalez-Cebrino F, Delgado J, Lozano M, Hernandez T, Ramirez R. 2011. Effect of Thermal and High-Pressure processing on the nutritional value and quality attributes of a nectarine purée with industrial origin during the refrigerated storage. J. Food Sci., 76: 618-625. DOI: $10.1111 /$ j.1750-3841.2011.02129.x.

Harborne J, Williams C. 2000. Advances in flavonoid research since 1992. Phytochemistry, 55(6): 481-504.

Illeperuma CK, Nikapitiya C. 2002. Extension of the postharvest life of 'Pollock' avocado using modified atmosphere packaging. Fruits, 57: 287-295. DOI: 10.1051/fruits:2002025.

Ishaq S, Rathore HA, Majeed S, Awan S, Shah SZA. 2009. The study on the physico-chemical and organoleptic characteristics of apricot produced in Rawalakot, Azad Jammu and Kashmir During Storage. Pak. J. Nutrition, 8(6): 856-860.

Kader AA, Mitchell FG. 1989. Postharvest physiology. In: La Rue, J.H.; Johnson, R.S.; (eds) Peaches, Plums and Nectarines: Growing and Handling for Fresh Market. University of California Department of Agriculture and Natural Resources Publication 3331: 158-164. ISBN: 0931876-88-5.

Kader AA, Watkins CB. 2000. Modified atmosphere packaging toward 2000 and beyond. Hort Technol., 10: 483-486.

Kader AA, Saltveit ME. 2003. Atmosphere modification. In: Bartz J, Brecht J (eds) Postharvest physiology and pathology of vegetables. Marcel Dekker, Inc., New York, 229-246. ISBN: 9780824706876.

Kadu RV, Gajipara NN. 2009. Effect of postharvest treatments on quality of sapota. Bioinfolet., 6(3): 271-273.

Karen LBG. 1991. Storage Conditions Fruits and Vegetables. In: "Postharvest Management of Commercial Horticultural Improving Postharvest Quality of Nectarine Fruits Crops". Co-op Extension, Kansas State University, Manhattan, Kansas, 1-7.

Kaynas K., Sakaldas M., Kuzucu FC. 2005. The effect of harvest time on fruit quality of "Tüysüz Beyaz Şeftali" population which grown in Çanakkale. III. National Storage and Marketing of Horticultural Products Symposium, September 6-9, 2005, Hatay. 64-71.

Khan AS, Ahmed MJ, Zora S. 2011. Increased ethylene biosynthesis elevates incidence of chilling injury in coldstored “Amber Jewel" Japanese plum (Prunus salicina Lindl.) during fruit ripening. Int. J. Food Sci. Technol., 46: 642-650. DOI: 10.1111/j.1365-2621.2010.02538.x.

Kostekli M, Ozdzikicierler O, Cortes C, Zulueta A, Esteve M.J. 2016. Role of potassium permanganate ethylene on physicochemical. properties, during storage of five different tomato cultivars. MOJ Food process Technol., 3(2): 1-9. DOI: mojfpt.2016.03.00069.

Lee SK, Kader AA. 2000. Preharvest and postharvest factors influencing vitamin $\mathrm{C}$ content of horticultural crops. Postharvest Biol. Technol., 20: 207-220. DOI: 10.1016/S0925-5214(00)00133-2.

Lill RE, O'Donoghue EM, King GA. 1989. Postharvest physiology of peaches and nectarines. Hort. Rev. 11: 413452. DOI: 10.1002/9781118060841.ch10.

Lopez-Rubio A, Almenar E, Hernandez-Munoz P, Lagaron JM, Catala R, Gavara R. 2004. Overview of active polymerbased packaging technologies for food applications. Food Reviews International, 20(4): 357-387. DOI: 10.1081/FRI200033462.

Lurie S, Crisosto $\mathrm{CH}$, 2005. Chilling injury in peach and nectarine. Postharvest Biol. Technol., 37: 195-208. DOI: 10.1016/j.postharvbio.2005.04.012.

Maftoonazad N, Ramaswamy HS, Marcotte M. 2008. Shelf-life extension of peaches through sodium alginate and methyl cellulose edible coatings. Int. J. Food Sci. Technol., 43(6): 951-957. DOI: 10.1111/j.1365-2621.2006.01444.x.
Mehyar GF, Han JH. 2011. Active packaging for fresh-cut fruits and vegetables. In Modified Atmosphere Packaging for Fresh-Cut Fruits and Vegetables (A.L. Brody, H. Zhuang and J.H. Han, eds.) pp. 267-283, Blackwell Publishing Ltd, UK. ISBN: 978-0-470-95910-7.

Mir AA, Sood M, Bandral JD, Gupta N. 2018. Effect of active packaging on physico-chemical characteristics of stored peach fruits. Journal of Pharmacognosy and Phytochemistry, 7(1): 886-890.

Özdemir AE, Ertürk E, Çelik M, Dilbaz R. 2006. The cold storage of Venus nectarin cultivars. Journal of Tekirdag Agricultural Faculty, 3(3): 297-304.

Özkaya O, Yildirim D, Dündar Ö, Tükel SS. 2016. Effects of 1methylcyclopropene (1-MCP) and modified atmosphere packaging on postharvest storage quality of nectarine fruit. Scientia Horticulturae, 198: 454-461. DOI: 10.1016/j.scienta.2015.12.016.

Pesis E, Ackerman M, Ben Arie R, Feygenberg O, Feng X, Apelbaum A, Goren R, Prusky, D. 2002. Ethylene involvement in chilling injury symptoms of avocado during cold storage. Postharvest Biol. Technol., 24: 171-181. DOI: 10.1016/S0925-5214(01)00134-X.

Reboucas JL, Machado FLC, Afonso MRM, Costa JMC. 2013. Postharvest conservation of papaya formosa conditioned under different packaging systems. Int. J Sci., 2: 57-65.

Rickman JC, Barrett DM, Bruhn CM. 2007. Nutritional comparison of fresh, frozen and canned fruits and vegetables. Part 1. Vitamins $\mathrm{C}$ and $\mathrm{B}$ and phenolic compounds. Journal of the Science of Food and Agriculture, 87: 930-944.

Saltveit ME. 1999. Effect of ethylene on quality of fresh fruits and vegetables. Postharvest Biol. Technol., 15, 279-292. DOI: 10.1016/S0925-5214(98)00091-X.

Sardabi F, Mohtadinia J, Shavakhi F, Ashraf JA. 2014. The effects of 1-methylcyclopropene (1-MCP) and potassium permanganate coated zeolite nanoparticles on shelf life extension and quality loss of golden delicious apples. Journal of Food Processing and Preservation, 38: 21762182. DOI: $10.1111 /$ jfpp. 12197.

Sen C, Mishra HN, Srivastav P.P. 2012. Modified atmosphere packaging and active packaging of banana (Musa spp.): A review on control of ripening and extension of shelf life. Journal of Stored Products and Postharvest Research, 3(9): 122-132. DOI: 10.5897/JSPPR11.057.

Sharma S, Sharma RR, Pal RK, Jhalegar MJ, Singh J, Srivastava M, Dhiman MR. 2012. Ethylene absorbents influence fruit firmness and activity of enzymes involved in fruit softening of Japanese plum (Prunus salicina L.) cv. Santa Rosa. Fruits, 67: 257-266. DOI: 10.1051/fruits/2012021.

Silva DFB, Salomao LCC, Siqueira DLD, Cecon PR, Rocha A. 2009. Potassium permanganate effects in postharvest conservation of the papaya cultivar Sunrise Golden. Pesquisa Agropecuaria Brasileira, 44(7): 669-675. DOI: 10.1590/S0100-204X2009000700003.

Smith AJ, Poulston S, Rowsell L, Terry LA. Anderson JA. 2009. A New palladium-based ethylene scavenger to control ethylene-induced ripening of climacteric fruit. Platin. Met. Rev., 53: 112-122. DOI: 10.1595/147106709x462742.

Slinkard K, Singleton VL. 1977. Total phenol analyses: Automation and comparison with manual methods. American J. Enol. Vitic., 28:49-55.

Sujayasree OJ, Fasludeen NS. 2017. Potassium Permanganate $\left(\mathrm{KMnO}_{4}\right)$ as an Effective Anti-Ethylene Agent to Delay Fruit Ripening: Recent Advances. Res J. Chem. Environ. Sci., 5(2): 73-76.

Tomas-Barberan FA, Espin JC. 2001. Phenolic compounds and related enzymes as determinants of quality in fruits and vegetables. J. Sci. Food Agric., 81: 853-876. DOI: $10.1002 /$ jsfa. 885 . 
Valenzuela JL, Manzano S, Palma F, Carvajal F, Garrido D, Jamilena M. 2017. Oxidative stress associated with chilling injury in immature fruit: postharvest technological and biotechnological solutions. Int. J. Mol. Sci., 18: 1467. DOI: 10.3390/ijms18071467.

Wang H, Cao G, Prior RL. 1996. Total antioxidant capacity of fruits. J. Agric. Food Chem., 44: 701-705. DOI: 10.1021/jf950579y.

Wills RBH, Warton MA. 2004. Efficacy of potassium permanganate impregnated into alumina beads to reduce atmospheric ethylene. J Amer. Soc. Hortic. Sci., 129: 433438 .
Zhao X, Zhang W, Yin X, Su M, Sun C, Li X, Chen K. 2015. Phenolic composition and antioxidant properties of different peach [Prunus persica (L.) Batsch] cultivars in China. International Journal of Molecular Sciences, 16(3): 57625778. DOI: $10.3390 /$ ijms 16035762 .

Zhishen J, Mengcheng T, Jianming W. 1999. The determination of flavonoid contents in mulberry and their scavenging effects on superoxide radicals. Food Chemistry, 64: 555559 . 